\title{
Managers and Employees' Perception of the Impact of Electronic Banking on Bank Operational Efficiency. A Case of Commercial Banks in Zimbabwe
}

\author{
Simon Muwando \\ PhD in Finance Candidate, Department of Banking, Faculty of Commerce \\ National University of Science Technology (NUST), Zimbabwe. \\ Email: simonmuwando@gmail.com or mnd@tsamail.co.za \\ Milton Webb \\ Executive Dean, Faculty of Commerce, National University of Science Technology (NUST), Zimbabwe. \\ Email: mwebb@nust.ac.zw
}

\section{Doi:10.5901/mjss.2014.v5n23p85}

\section{Abstract}

The main objective of the paper is to assess the managers and employees' perception of the impact of electronic banking on operational efficiency of commercial banks in Zimbabwe. An exploratory research design was employed to address the objectives of the study. Fifteen commercial banks operating in Bulawayo were chosen. The sample of the study consists of eighty participants composed of sixty management staff and twenty employees. A questionnaire and personal interviews were used to solicit information from the participants. The results revealed that electronic banking enhanced the operational efficiency of the commercial banks in Zimbabwe. There is need for the government to improve its legislation and telecommunication infrastructure for the banks to enjoy on a full scale the benefits of electronic banking.

Keywords: Electronic banking, operational efficiency, Commercial Banks, Zimbabwe

\section{Introduction}

Electronic banking is an extremely powerful delivery channel that offers many opportunities for growth and development of commercial banks. It has become an essential tool for technological advancement in the banking sector as it facilitates provision of financial products and services efficiently and effectively [1]. In Zimbabwe, the first visible form electrical innovation was in the early 1990s when Standard Chartered bank and Central African Building Society (CABS) installed Automated Teller Machines (ATMs) followed by Electronic Funds Transfer System (EFTs),Telephone banking, personal Computer(PC) banking, Internet banking which were later introduced into the country[2]. Despite the adoption of electronic banking in Zimbabwean, commercial banks had problems in providing efficient services to their customers especially during the period 2003 to 2008 when the economy was under an economic crisis [3]. At present, even though the adoption of the multicurrency system in 2009 has stabilized the economy banks still face operational challenges. This assertion is evidenced by the high transaction costs and service fees on both savings and current accounts that range from $1 \%$ to $3 \%$ of the amount in case of withdrawals. Moreover, service quality is being compromised as commercial banks still rely more on the traditional method which is time consuming and characterized by long queues. Customers have to wait for the next cash deposit to withdraw their money. Is it electronic banking which led to operational inefficiency of commercial banks? [5] discussed briefly about the impact of e-banking on operational efficiency as they indicated that it led to systems reliability but they did not go into detail to discuss the management and employees' perception of the impact of e-banking on other indicators of operational efficiency of a bank. This motivated the researchers to investigate in detail the managers and employees' perception of the impact of e-banking on operational efficiency.

\section{Literature Review}

\subsection{Electronic Banking}

There is not much difference in the definitions of electronic banking (e-banking) by various authors. [2] defined e-banking 
as the systems that enable bank customers to access their accounts and general information on bank products and services through the use of banks' website, without the intervention or inconvenience of sending letters, faxes, original signatures and telephone confirmations. According to [4], e-banking refers to the provision of retail and small value banking products and services through electronic channels. Such products and services can include deposit-taking, lending, account management, the provision of financial advice, electronic bill payment, and the provision of other electronic payment products and services such as electronic money. In [5] citing [6] and [7] internet banking is viewed as a process innovation whereby customers handle their own banking transactions without visiting bank tellers. E-banking includes the systems that enable financial institution customers, individuals or businesses, to access accounts, transact business, or obtain information on financial products and services through a public or private network, including the internet or mobile phone [8]. Therefore, e-banking can be viewed as a service that allows customers to do their traditional banking services through electronic channels without visiting a brick and mortar facility [9]. Technological innovations have been identified to contribute to the distribution channels of the banks and these delivery channels are collectively referred to as e-banking [10]. There are five different channels for e-banking namely PC banking, internet banking, managed network, mobile banking and TV-based banking.

\subsection{Operational Efficiency}

PC and Internet usage has doubtlessly created cost reductions and consumer surpluses, especially with regard to online banking and brokerage services [11]. Operational efficiency is defined as an examination of how well banks combine their resources to support the largest possible number of transactions at lower costs [12]. Efficiency measurements, of course, imply knowledge of the inputs and outputs of a bank. Empirical literature has two main models for measure bank operational efficiency, that is, the production approach or intermediate approach. The researchers adopt the production approach as it is the most evidence. Production approach to operational efficiency assumes the resources of a bank as inputs (e.g personnel, technology, space etc) and output as some measurable form of services provided (eg number of accounts processed, or loans and other transactions processed etc) as shown in Figure 1 overleaf.

Figure 1: The inputs and outputs model of the production model for benchmarking the operational efficiency of a bank branch

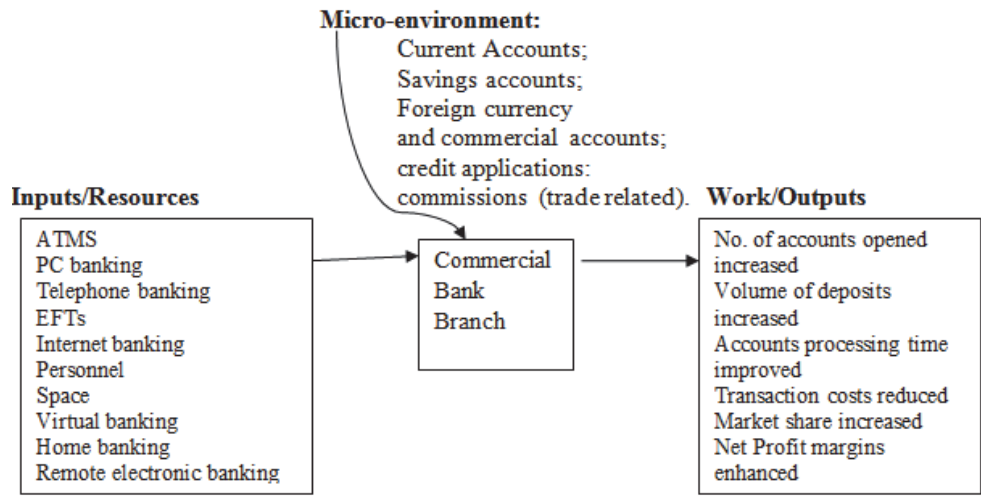

Source: Adopted from [12] and modified by the researchers

\section{Research Methodology}

To address the main objective, an exploratory research was used by the researchers because it allowed the research to familiarise with the problem and concept studied. The assessment was carried out on the following 15 commercial banks namely Ecobank, Barclays, CBZ, FBC, Kingdom, MBCA, Metropolitan, NMB, Stanbic, Standard Chartered, TN bank rebranded to Steward Bank, ZB Bank and Allied Bank, Banc ABC and EcoBank (formerly Premier banking Corporation) as they had established their presence in the commercial banking business in the period under study that is from 2000 to 2013. Bank branches in Bulawayo make up the population because of proximity to the researcher. The targeted population consisted of both management and employees with more than 10 years working at the bank because there have a better knowledge about e-banking. Simple random sampling is the main sampling technique which was used by 
the researcher because of the small population size. This method allows each individual within the population an equal chance of selection. The research questionnaire design was pre-tested and redesigned through personal interviews with bank managers by undertaking pilot study [13]. At least four questionnaires were submitted to every commercial bank under assessment. In order to compliment and reinforce the data acquired from the questionnaires, personal interviews were done on carefully selected banks which Kingdom bank that successfully launched Cell card, CBZ, Barclays, ZB, Stanbic, Stanchart, FBC, NMB, MBCA and Steward bank. The banks that were chosen were selected because they had more vibrant e-banking products that they were using to deliver service to customers than other banks.

\section{Findings and Discussion}

\subsection{Questionnaire Response Rate}

The findings are based on the $88 \%$ response rate as indicated by Table 1 :

Table 1: Questionnaire response rate

\begin{tabular}{|l|c|c|c|}
\hline Targeted Respondents & Questionnaire Distributed & Questionnaire returned & Response rate from each bank \\
\hline CBZ Bank & 6 & 4 & $67 \%$ \\
\hline Kingdom Bank & 6 & 4 & $67 \%$ \\
\hline MBCA Bank & 6 & 4 & $67 \%$ \\
\hline BANC ABC & 6 & 2 & $33 \%$ \\
\hline FBC Bank & 6 & 6 & $100 \%$ \\
\hline Steward Bank & 4 & 4 & $100 \%$ \\
\hline NMB bank & 6 & 6 & $100 \%$ \\
\hline Metropolitan Bank & 4 & 4 & $100 \%$ \\
\hline Allied Bank & 4 & 4 & $100 \%$ \\
\hline Stanbic Bank & 6 & 6 & $100 \%$ \\
\hline Barclays Bank & 6 & 6 & $100 \%$ \\
\hline Stanchart Bank & 6 & 6 & $100 \%$ \\
\hline ZB Bank & 6 & 6 & $100 \%$ \\
\hline Trust Bank & 4 & 4 & $100 \%$ \\
\hline Ecobank & 4 & 4 & $100 \%$ \\
\hline TOTAL & 80 & 70 & $88 \%$ \\
\hline
\end{tabular}

The response rate from all the banks was fairly high because the respondents were cooperative. Management were given sixty questionnaires while employees were give twenty questionnaires because management has more knowledge of e-banking than employees and they are ones who are in a position to disclose the impact of e-banking on bank operational efficiency. Thus, out of the seventy questionnaires returned, fifty-two were distributed to management and the remainder to employees and the findings from both management and employees were combined.

\subsection{Interview response rate}

Out of the ten interviews done there was a 100\% response rate as the interviewees were accommodative. These interviews were also quite prolific as they were able to clear some questions raised that were not clear from the answers obtained from questionnaires.

\subsection{Impact of e-banking on operational efficiency of commercial banks}

The Impact of e-banking on operational efficiency of commercial banks was subdivided into the following components listed in Table 2 and the respondents were asked to tick. 
Table 2: Impact of e-banking on operational efficiency of commercial banks

\begin{tabular}{|l|c|c|c|c|}
\hline Impact & Strongly Agree & Agree & Disagree & Strongly Disagree \\
\hline Reduced transaction costs & $95 \%$ & $2 \%$ & $3 \%$ & $0 \%$ \\
\hline Lower transaction processing time & $97 \%$ & $3 \%$ & $0 \%$ & $0 \%$ \\
\hline Increased usage space & $98 \%$ & $2 \%$ & $0 \%$ & $0 \%$ \\
\hline Volume of deposits increased & $95 \%$ & $5 \%$ & $0 \%$ & $0 \%$ \\
\hline Improved clientele base & $40 \%$ & $15 \%$ & $28 \%$ & $17 \%$ \\
\hline Improved productivity & $70 \%$ & $3 \%$ & $15 \%$ & $12 \%$ \\
\hline Enhance net operating margin & $60 \%$ & $35 \%$ & $5 \%$ & $0 \%$ \\
\hline Positive effect on operational efficiency (Overall) & $90 \%$ & $10 \%$ & $0 \%$ & $0 \%$ \\
\hline
\end{tabular}

Source: primary data

The respondents (management and employees) revealed that e-banking reduced transaction costs of Zimbabwean commercial banks as 95\% strongly agree, $2 \%$ agree while 3\% disagree because they had not yet experienced any positive impact. This concurs with [14] and [15] who point out that each ATM has the capacity to carry out the same, essentially routine, transactions as do human tellers in branch offices but at half the cost and with a four to one advantage in productivity. This is further reinforced by [16] who also assert that typical ATM transaction is a fraction of the cost of teller transactions as shown Figure 2:

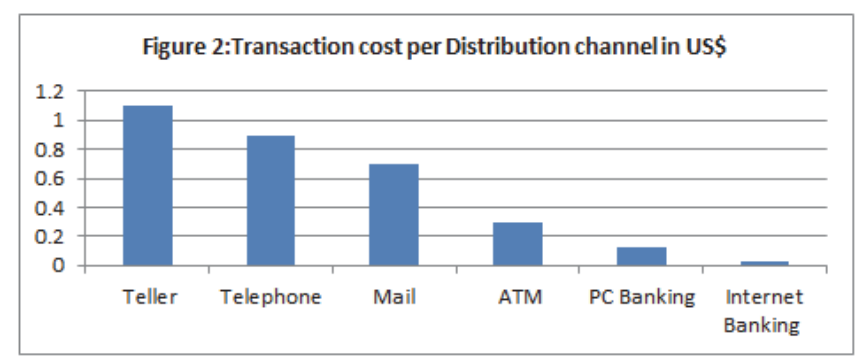

Source: Ketley and Duminy (2003)

They also cite that e-banking reduced transaction processing time because the systems were working efficiently and effectively. This concurs with a study by [17] which indicates that online banking saving time and [5] who cites that ebanking does not lead to high transaction processing errors. Respondents also indicated that adoption of e-banking increased usage space as their transaction volume within the banking halls decreased. Most of the banks space is used to generate revenue and provide advice to customers [16]. Volume of deposits increased as indicated by the results. This might be as a result of acceptance e-banking by the customers and also increase in the number of customers' accounts opened after the adaption of e-banking. The findings also indicated that e-banking improves clientele base of some banks while did change the clientele base of others. This might be due to the fact that most rural areas (potential market for banks) in Zimbabwe do not have electricity. For the banks whose clientele base improved, this in line with [18] citing in [19] who pointed out that organisation that use e-commerce techniques and technology attract additional consumers because of higher level of customer service. Other impacts of e-banking are improved productivity and net operating margin as indicated by the respondents. Overally, the findings revealed that e-banking enhances the operational efficiency of the banks because $90 \%$ and $10 \%$ of the respondents ticked under strongly agree and agree respectively. This is consistent with [18] who point out that e-banking reduces cost of doing business through reduction of wage bill and intermediaries, thus, banks can interact directly with their customers.

The results of the interview also revealed that e-banking improved operational efficiency of the commercial banks as their operational costs decreased by wider margin while their operating margin increased. They further indicated that their customers can enquire account balances, bank statement, pay their bills through sms.

\subsection{Critical Success Factors (CSF) for e-banking adoption in Zimbabwe}

The respondents were given a list of CSFs asked to tick and the results shown in Figure 3: 
Figure 3: Response rate for CSF for the adoption of e-banking

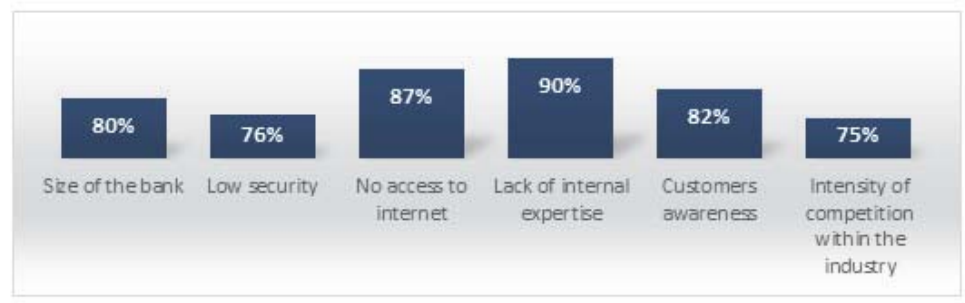

Source: primary data

The research findings revealed that $80 \%$ of the respondents were of the view that the size of the bank is a CSF for ebanking adoption while $20 \%$ had a different view. This is in line with [20], [21] and [1] who pointed out that the small size of the bank hinders the adoption of e-banking and usually small banks owned by indigenous people in Africa are less pertinent to adopt to e-banking because the often lack resources. $76 \%$ of the respondents pointed out security as another CSF whilst $24 \%$ disagreed. Internet access has also been considered a CSF by $87 \%$ of the respondents whilst $13 \%$ had a different view. Furthermore, $90 \%$ of the respondents pointed out lack of internal expertise another CFS whilst the remainder contradicts with that view. This concurs with [22] and [23] cited by [18] who stated that one of the reason for not adopting e-banking is lack of expertise and that is the reason why many organizations have delayed the adoption of e-banking. The other factors indicated were customer awareness and intensity of the completion within the banking industry. Respondents further cited additional CFSs that are necessary for the adoption of electronic banking: upgrading existing technology infrastructure, fast and efficient internet, resistance of change from traditional model of banking to ebanking, top management support and excellent customer service. This is also supported by [24], [25], [26], [27], [28] and [29].

\section{Conclusion}

Despite the liquidity challenges facing the Zimbabwean banking sector in the post-dollarization period, commercial banks have fully adopted the e-banking channel of distribution of products and services. The findings of the research indicate that management and employees perceived that adoption of e-has positively impact on operational efficiency of the commercial banks through reduction in transaction costs, increased usage space, enhancement of volume of deposits as a result of increase in the number of customers' accounts processed, increase in net operation margin and reduction of operational costs of the banks. For these banks to fully enjoy the fruits of e-banking there is need for improvement of internet connectivity and other telecommunication infrastructure, legislation, educate the customers on what e-banking is? its benefits and risks? imparting knowledge and skills about e-banking to the internal members of staff.

\section{References}

Poon WC (2008), Users' Adoption of e-banking services: The Malaysian Perspective" J.Bus. Industrial Market., Vol. 23(1):59-69

D.Thulani, C.Tofara , and R, Langton, "Adoption and Use of Internet Banking in Zimbabwe: An Exploratory Study", journal of internet banking and commerce, vol. 14, 2009

Reserve Bank of Zimbabwe (RBZ) (2011), Monetary Policy Statement, Harare.

Basel Committee on Banking Supervision, Risk Management Principles for Electronic Banking, Bank for International Settlements, 2003 Ndlovu I and Sigola (2013), The Benefits and Risks of Electronic Banking: The case of Commercial Banks in Zimbabwe, Vol.2 (4) 34-40

Chang Y.T. (2003) "Dynamics of Banking Technology Adoption: An Application to Internet Banking, Department of Economics", Workshop Presentation, University of Warwick, Coventry, UK .

Sullivan R. and Wang Z. (2005) "Internet Banking: An exploration in Technology Diffusion and Impact", Working Paper No. 05-05. Payments Systems Research Department, Federal Reserve Bank of Kansas City.

Daniel, E. (1999). Who dares wins? On-line banking services and innovation types. In: Hackney, R. (Ed.). Proceedings of ninth annual business information technology conference, paper no. 34. November 3-4, Manchester, UK

Pedro,I (2012) "Towards effective implementation of electronic banking in Nigeria." African Research Review. An International Multidisciplinary Journal, Vol 6 (2) 290-300.

Goi C.I (2005) "E-banking in Malaysia: Opportunities and challenges", Journal of internet Banking and Commerce Vol. 10 No.3, Dec 2005 
Gordon, R. (2000), Does the new economy measure up to the great inventions of the past?, Journal of Economic Perspectives, Vol.14 (4), pp. 49-74.

Sherman, H.D and Gold, F (1985). Bank branch operating efficiency: Evaluation with data envelopment analysis. Journal of Banking and Finance, 9: 297-315.

Aaker, D., Kumar.V, and Day G (2003). Marketing research. 800 p. $7^{\text {th }}$ ed., John Wiley and Sons, New York, USA

Booz-Allen \& Hamilton, (2003), "Processing Cost Per Transaction", JP Morgan

Jayawardhera C and Foley P (2000) "Changes in the banking sector-The case of internet banking in the UK", Electronic Networking Applications and Policy, Vol.10 (1), pp. 19-30, MCP UP.

Ketley, R and Duminy, B., (2003) "Briefing Note\#21, Meeting the challenge - The impact of changing technology on MicroFinance Instituions", MicroSave.

Booz, Allen and Hamilton (1997). Internet banking: a global study of potential. Booz, Allen \& Hamilton Inc., New York, NY.

Dzama T and Matavire E (2013), E-Commerce Adoption in banking sector in Zimbabwe. Case of Commercial Bank of Zimbabwe (CBZ), International Journal of applied research and studies, Vol. 2(6) pp. 1-12.

Espstein, M.J (2004). Implementing E-commerce strategies: A guide to corporate success after the dot.com bust. Westerport: Praeger Publishers.

Huy, L.V., Filiatrault, P. (2006), "The adoption of e-commerce in SMEs in Vietnam: a study of users and prospectors", Proceedings of the tenth Pacific Asia Conference on Information Systems (PACIS 2006), Kuala Lumpur, Malaysia, July 2006,

Burke RR (2002). "Technology and the customer interface:What consumers want in the end-user computing satisfaction of online banking services: Empirical evidence from Finland", int.J.Bank Market...,24(2/3) 158-67.

Laudon K and Traver, C (2008), E-commerce: Business Technology, Society, $4^{\text {th }}$ Edition Prentice hall, Uppuer Saddler River, New Jersey.

Gonzalez ME, Dentiste MR, Rhonda MW (2008)."An alternative approach in service quality: An E-banking case study", The Quality Management Journal, 15(1):41

Regan, K and Macauso N.(2000),Report: Consumers cool to net banking. E-Commerce Times, October 3,2000, http://www. ecommercetimes.com/news/articles2000/001003-4.shtml

Orr.B. (2004), E-Banking job one: Give customers a good ride.ABA Banking Journal, Vol.96 (5) , pp56-57.

Franco,S.C., and Klein,T(1999) Online Banking Report, Piper Jaffray Equity Research, www.pjc.com/ec-ie01.asp?team=2

Enos, L.(2001) Report: Critical errors in online banking. Ecommerce Times,11 April, Wysiwyg://4/http://www.ecommercetimes.com/ perl/story/8867.htm

Storey, A., Thompson, J.B., Bokma. A and Bradnum, J. (2000). An evaluation of UK and USA online banking and websites, in Chung, H.M. (Ed) Proceedings of the Americas Conference on information Systems, August 10-13,200, Long Beach, California, USA,Vol.2, pp.723-728.

Yoursfzai, S.Y. Pallister, J.G. and Foxall, G.R (2003) A proposed model of e-trust for electronic banking Technovation, Vol.23, pp 847860 . 